\title{
A Review of Existing Debates That Have Persisted Over the Choice of Language as a Medium of Instruction in Ghanaian Classrooms
}

\author{
Gifty Edna Anani \\ Department of Public Relations, University of Professional Studies, Accra, Ghana \\ E-mail: gifty.anani@upsamail.edu.gh
}

Received: May 10, 2019 Accepted: June 29, 2019 Published: July 2, 2019

doi: 10.5296/ire.v7i2.15013 URL: https://doi.org/10.5296/ire.v7i2.15013

\begin{abstract}
The choice of language to use as a medium of instruction across the curriculum in schools has been a contentious issue in Africa. Ghana, like many multilingual African countries, has not been spared this serious challenge of language choice. In fact, it has become a worrying issue of concern to many Ghanaians who have an interest in education. This paper provides snapshots of varied opinions on selecting a language as a medium of instruction in Ghanaian classrooms. It discusses the existing debates on the use of English language as a medium of instruction and also asserts the writer's stance on the subject. Finally, the paper concludes by advocating the support for Ghanaian languages as a medium of instruction across the curriculum at the lower primary level.
\end{abstract}

Keywords: Debates, Language, Medium of instruction, English language, Indigenous language

\section{Introduction}

Language is a medium of communication, business, scientific development, and practically everything we do. Hence, the language of education of any country is a very important factor for national development (Ashraf, 2012). Unfortunately, many African countries have not permanently settled on which language to use as medium of instruction. We have swung from the languages of our colonial masters to our indigenous languages. For instance, Ghana, a highly multilingual country with over forty spoken indigenous languages (Edward, 1983; Dakubu, 1988; Andoh-Kumi, 2000), has not been able to follow a consistent language policy. The aim of this current paper is to review debates on language policy adopted in Ghana since the introduction of formal education in the country. It starts with a brief historical account of 
controversies on educational language policy in the country. After that, an analysis of the manner in which the various policies were formulated is presented and concluded with the case for the support of the current language policy.

\section{English Language Policy Controversy in Ghana}

Various researches and personalities have expressed views and opinions on the use of the English Language as the sole language of instruction in Ghanaian schoolls. In the Ghanaian classrooms, indigenous languages were used as language across the curriculum at the lower level of education from 1971 to 2001. In May, 2002, Ghana instituted a policy which adopted the English language as a language across the curriculum from primary one to three to replace the use of indigenous languages as the medium of instruction for the first three years of schooling, and English continued as the medium of instruction from primary four onwards (Owu-Ewie, 2006). This all-English policy was initiated by Professor Ameyaw Ekumfi, the then Minister of Education. In fact, this policy sparked a lot of criticisms from educational stakeholders but their requests fell on deaf ears. The Minister gave a tall list of reasons for that dramatic change. Owu-Ewie, (2006) listed the following reasons for the change of the language policy:

- Constant use of the target language (English) by the instructors for lesson delivery will build pupils' English language proficiency.

- Most Schools in Ghana were operating without textbooks in Ghanaian languages to enhance teaching and learning. There is hardly any standard written form of many Ghanaian languages.

- The old policy of using Ghanaian languages as medium of instruction at the lower primary level was abused by teachers, especially in rural areas where some teachers never expressed themselves in English even in primary six. This made some pupils from the rural areas unable to speak and write correct expressions even by the time they complete senior high school.

- The multilingual situation of the country, especially in urban schools, made instruction in the indigenous languages very difficult. To add to this, about fifty to sixty percent of children in each class in urban areas spoke a different language. According to the Ministry of Education, (2003) "It was therefore a serious issue if the government insist that all the children to be taught in Ga, Twi, or Dagbani depending on whether it is Accra, Kumasi or Tamale."

- Another major issue raised was that there were no language teachers specifically trained to teach content subjects in the Ghanaian language. There was no standard written form of the Ghanaian languages.

- There was a lack of teaching and learning aids in the Ghanaian languages to be used in teaching. The Minister of Education also declared that "Only five of the languages that are spoken by our major ethnic groups have materials developed on them.

From the last assertion, the government cannot force the entire nation to adopt the five languages, leaving other languages.

In order to substantiate the claims for the use of English as the medium of instruction, the minister pointed out that English is the medium of instruction of the state and that all efforts must be put in place, to ensure that school children acquire the right level of language proficiency in both the spoken and written forms of the language. 
Critics to the change, including linguists, educationists and politicians argued to the extent of calling for a total rejection of the English language as the medium of instruction. Those who opposed the minister's reasons also pointed out that English did not promote the linguistic rights of children and it deprived Ghanaian students of their rich cultural heritage, identity and values. This debate persisted for a very long time without any resolution.

In 2015, the issue resurfaced. Professor Naana Opoku Agyeman, the then Minister of Education, called for a shift from English to local languages as a medium of instruction with the reason that the standards of education could improve with the introduction of local languages. A few days after her publication, other researchers poured in their reactions. A renowned researcher of education, Dr. Michael J.K. Bokor condemned the minister's position as untenable and baseless.

\section{Researchers Advocating for English as a Medium of Instruction}

According to Bokor (2015), our colonizers instituted formal education in the country with the English language as the Lingua Franca and a subject of study. Since then, English has taken over the languages and virtually killed indigenous languages in the curriculum. He advanced the following reasons why English should be maintained as the medium of instruction:

1) The Ajumako School of Languages established by Osagyefo Kwame Nkrumah to train teachers for the local languages was neglected by successive governments and therefore there was no proper college to train teachers for Ghanaian languages.

2) In the age of technological advancement, the local languages were not found in the orthographical repertoire so it would be difficult to introduce Ghanaian languages on the computer.

3) It was very difficult to choose a local language for metropolitan areas like Tema, Kumasi, and Accra.

4) Teachers were not well trained in the local languages. The majority of our teachers could not even read and write in their native languages.

In advancing support for English as a medium of instruction at the lower primary level, it would be necessary to refer to Ankrah (2015). He reported in his dissertation that trainee teachers in our colleges of education were in favour of the use of English as a language across the curriculum at the lower primary level. His respondents in this study were also convinced that English as a global language would enable students to communicate with people from other parts of the world. Again, they condemned Ghanaians' negative attitude towards Ghanaian languages and teachers of Ghanaian languages and pointed out that parents opted to send their wards to international schools, where English was the only medium of instruction at all levels. These factors undoubtedly would hinder any attempt to adopt any language policy that favoured Ghanaian languages over English.

Other factors mentioned in his findings included, poorly-arranged teacher postings and supervision. Ghanaian language teaching in basic schools was reported to be of low quality because after training, teachers were often posted to areas where the dominant local language differs from theirs. He concludes that since English is the official language, there is no harm in teaching in it throughout the elementary schools.

Another scholar, who added his voice against the Ghanaian languages policy debate was 
Odjidja (2015). He argues, "The "mother tongue" is the perfect tool for tribalism. It is not seen as a unifier of the nation". He warns that tribalism owes its strength to a common language. And to put a "mother tongue" in the wrong classroom would give up troubles for a multi-cultural area such as Accra. The "mother tongue" can be a subject of study in the schools. He admitted that our mother tongue is a source of our cultural pride but it should not replace English as the medium of instruction. In spite of the love for "mother tongue" good African literature cannot be seen in translations in our local languages. To add to his reasons, he indicates, "The English language has given Ghanaians easy access and clarity to much of existing literature and the exponential ability to connect with any part of the world.

The late Dr. K.B. Asante also shared the view expressed above. He advocated strongly for English Language to be retained as the medium of instruction in Ghanaian schools. He also backed his argument with the following reasons:

"There is the idea that English is the language of Ghana's social elite, and as well the language of modernization, it is advisable to use English as a medium of instruction.

He added that English is the official language; there is no harm in teaching in it throughout, even in the elementary schools. "We can teach in English language, our predecessors did that and they were not that bad" (Asante, 2017).

The current Minister for Education, Dr. Matthew Opoku Prempeh, also supports the idea of using English language as a medium of instruction. At his vetting by Parliament in 2016, he argued, "We train ourselves to become globally competitive." He implies that so long as English is used internationally and also it is the language for business and all official communication, it should be taught with all seriousness at all levels of edlucation. He further pointed out, "English has been accepted as the country's second language and it must be studied well." (Anopa Kasapa on Kasapa 102.5 FM).

\section{Writer's Stance on the Language Policy in Ghana}

As these debates rage on, the big question Ghanaians are still struggling with is the choice of language of instruction in our schools. What should the language of instruction be in our schools? Studying all sides of the language policy debates and research even beyond the borders of Ghana, it is surprising Ghana has not found the answer by now. Unfortunately, we haven't found better answers to curtail our language policy problems. We are still debating on the importance of indigenous Ghanaian languages in the childhood education. It is assumed that using the indigenous language as a medium of Instruction during the early years improves children's ability to acquire knowledge and also other languages. Their indigenous languages help them understand concepts being introduced to them. On the contrary, there are those who feel that a solid foundation in English offers children a better chance of succeeding in school and in their careers. Presently, some parents who agree to the use of English have taken the extra move of stopping the use of indigenous Ghanaian languages at home. They consider proficiency in English language as a major success. A pass in English Language is a necessary requirement for a student's progression from one educational level to another and also it is a mark of elitism in the Ghanaian society. Once one accepts to educate himself, one has no good reason not to speak English well. In fact, all the views expressed by all stakeholders for the change from the indigenous languages are tangible but lam opposed to 
these views on the following grounds:

My standpoint is in favour of the use of Ghanaian languages as medium of instruction instead of the English Language.

It will help us recognize and preserve our national identity. Trudell (2016) supports the position that children who are taught in their mother tongues tend to acquire new concepts and principles easier than languages that are foreign to them. It has also been established that the use of mother tongue as a medium of instruction at the lower classes help pupils to acquire the necessary skills needed in their formal education. The use of indigenous languages brings about cordial relationship between pupils and teachers. Since teachers are sometimes native speakers of the language they are able to express themselves fluently which promotes teaching and learning at the lower primary. In the rural areas most students do not understand the teacher when the English language is used as a tool for communication. Communication is very attractive and interesting when Ghanaian language is used because it is our local language.

The use of the learners' home language at the lower primary lessens the load on teachers, especially where the teacher speaks the local language of the pupils he or she teaches. From the researcher's teaching experience, in teaching and learning situations, where both the teacher and the pupil are non-native speakers of the medium of instruction, the pupils struggle to understand the key concepts being introduced to them. But when teaching is done in the teachers' and learners' native language, the teaching and learning experience is more natural and interesting for all. As a result, the teacher can be more creative in choosing the right teaching/learning materials and approaches, leading to effective teaching and learning in the various classrooms.

Frankly, concepts taught in the learners' indigenous language do not have to be re-taught when they switch from indigenous language to English Language. Also, a learnerwho acquires reading and writing skills in the indigenous language would easily transfer to any new language which would be introduced to them. When learners start school in a language that is not familiar to them, teachers are forced to choose teacher-centred teaching approach and this calls for non-participation of students in classrooms. Kioko (2015) As a result, it suppresses young learners' potential and liberty to speak freely. This in turn inhibits pupils' creativity, and makes the learning experience unpleasant and difficult for both teachers and learners. In fact all of these challenges bring about negative effects on learning outcomes in our classrooms.

\section{Conclusion}

In the final analysis, refuting all these contentions of those scholars advocating English as a medium of instruction. Our indigenous languages are central to our development and also the use of learners' home language in the classroom helps the learners to connect smoothly from home to the school. This means learners get more involved in the learning process as it speeds up the development of basic skills such as literacy. It also enables more flexibility and creativity in teaching and learning. Using learners' home language is also more likely to attract the members of the communities to get on board, where the various schools are situated to support teaching/learning and this will really inform teaching and learning in our schools. 


\section{References}

Ameyaw- Akumfi, C. (2002, August 29). Government approves new language policy. Accra Mail. Accra, Ghana. Retrieved on August 30, 2018 from ghanaweb.com.

Ameyaw- Akumfi, C. (2002, May 17). English only, no more vernacular. People's Daily Graphic. Accra, Ghana. Retrieved on June 18, 2018 from ghanaweb.com

Ameyaw-Akumfi, C. (2002, July 16). New language policy for primary and basic education. The Statesman .Accra, Ghana. p. A7 Retrieved on July 2018

Ankrah, T. O. (2015). Education Experts' Perceptions of the Ghanaian Language Policy and Its Implementation; Academic dissertation, University of Lapland.

Asante, K. B. (2017). Keep English as medium of instruction in schools. Retrieved from https://www.ghanaweb.com/Ghana

Bogale, B. (2009). Language determination in Ethiopia: What medium of instruction? Proceedings_of the 16th Conference of Ethiopian Studies. Retrieved from https://www.booksforafrica.org/assets/documents/2013-ASA-Conference---English

Borkor, M. J. K. (2015). English no more the medium of instruction in Ghanaian schools.

Bunyi, G. (1999). Rethinking the place of African indigenous languages in African education. International Journal of Educational Development, 19(4-5), 337-350. https://doi.org/10.1016/ S0738-0593(99)00034-6

Crystal, D. (2003). English as a global language. Cambridge: Cambridge University Press. https://doi.org/10.1017/CBO9780511486999

Ministry of Education (2003). Executive summary of the president's educational review committee.

Mydans, S. (2007, April 9). Across cultures, English is the word. New York Times.

Odjidja, E. A. (2015). Mother tongue in Ghana schools, again? Ghanadot.com/commentaries

Owu-Ewie, C. (2003). Improving mother tongue education in Ghana at the lower primary level (P1-P3): A study of schools in Shama Ahanta East Metropolitan Assembly in Ghana. MA Thesis: Ohio University. https://doi.org/10.4314/gjl.v3i2.1

Owu-Ewie, C. (2006). The Language Policy of Education in Ghana: A Critical Look at the English-Only Language Policy of Education. In Selected Proceedings of the 35th Annual Conference on African Linguistics.

Sackey, J. (1997). The English Language in Ghana: A Historical Perspective. In Dakubu (Ed.). English in Ghana (pp. 126-139). Ghana Universities Press.

Sekyere, D. O. (2013). Some factors influencing the academic performance of junior high school pupils in English Language: The case of Assin North Municipality, Ghana.

\section{Copyright Disclaimer}

Copyright reserved by the authors.

This article is an open-access article distributed under the terms and conditions of the Creative Commons Attribution license (http://creativecommons.org/licenses/by/3.0/). 